DEMOGRAPHIC RESEARCH

VOLUME 36, ARTICLE 43, PAGES 1299-1336 PUBLISHED 25 APRIL 2017

http://www.demographic-research.org/Volumes/Vol36/43/

DOI: $10.4054 /$ DemRes.2017.36.43

Research Article

\title{
The impact of citizenship on intermarriage: Quasi-experimental evidence from two European Union Eastern enlargements
}

\section{Davide Azzolini \\ Raffaele Guetto}

This publication is part of the Special Collection "A New Look Into the Dynamics of Mixed Couples in Europe," organized by Guest Editors Amparo González-Ferrer, Laura Bernardi \& Alícia Adserà.

(C) 2017 Davide Azzolini \& Raffaele Guetto.

This open-access work is published under the terms of the Creative Commons Attribution NonCommercial License 2.0 Germany, which permits use, reproduction \& distribution in any medium for non-commercial purposes, provided the original author(s) and source are given credit. See http:// creativecommons.org/licenses/by-nc/2.0/de/ 


\section{Contents}

1 Introduction 1300

2 Citizenship acquisition and intermarriage 1302

3 The European Union Eastern enlargements and intermarriage in 1304

Italy

3.1 The discontinuity in immigrants' legal status brought about by the 1304 European Union Eastern enlargements

$\begin{array}{ll}3.2 & \text { Intermarriage in the Italian setting } \\ & 1306\end{array}$

$4 \quad$ Empirical strategy 1309

4.1 The synthetic control method 1309

4.2 Data and variables 1311

5 Empirical results 1315

5.1 SCM estimates 1315

$\begin{array}{lll}5.2 & \text { Significance tests } & 1319\end{array}$

$\begin{array}{lll}5.3 & \text { Robustness checks } & 1321\end{array}$

6 Conclusions 1322

$7 \quad$ Acknowledgments 1323

$\begin{array}{ll}\text { References } & 1325\end{array}$

$\begin{array}{ll}\text { Appendices } & 1331\end{array}$ 


\title{
The impact of citizenship on intermarriage: Quasi-experimental evidence from two European Union Eastern enlargements
}

\author{
Davide Azzolini ${ }^{1}$ \\ Raffaele Guetto ${ }^{2}$
}

\begin{abstract}

\section{BACKGROUND}

According to assimilation theory, the more immigrants are integrated within host countries the more likely they are to intermarry. However, status exchange theory argues instead that when integration is low, immigrants may use intermarriage as a means of improving their integration prospects in host countries, in which case an increase in levels of integration would reduce immigrants' propensity to intermarry.
\end{abstract}

\section{OBJECTIVE}

To test these two hypotheses, this paper assesses the causal effect of a positive shift in immigrants' level of integration, namely the acquisition of citizenship, on intermarriage in Italy. Over the past 20 years Italy has experienced an unprecedented growth in intermarriage involving primarily Eastern European women.

\section{METHODS}

We study two EU Eastern enlargements, following which citizens of the new EU member countries became EU citizens and thus experienced a marked improvement in their legal status. We apply the synthetic control method to data on marriages between native men and foreign women.

\section{RESULTS}

We find that the acquisition of citizenship has a significant negative impact on immigrant women's propensity to marry native men. That impact is much greater for immigrants coming from less affluent countries.

\footnotetext{
${ }^{1}$ Corresponding author. FBK-IRVAPP, Italy. E-Mail: azzolini@fbk.eu.

${ }^{2}$ University of Milano-Bicocca, Department of Sociology and Social Research, Italy.

E-Mail: raffaele.guetto@unimib.it.
} 


\section{CONCLUSIONS}

Our results support the status exchange hypothesis. This can be explained by the poor socioeconomic integration and precarious legal status of immigrants in Italy.

\section{CONTRIBUTION}

The growth of intermarriage per se cannot be seen as an indicator of greater immigrant integration. The negative impact of citizenship acquisition on immigrants' propensity to intermarry also calls for a rethinking of the role of institutions such as marriage and citizenship in the process of immigrant integration.

\section{Introduction}

Marriage between natives and immigrants is commonly understood to represent the height of immigrant assimilation and social integration (Gordon 1964; Alba and Golden 1986). Intermarriage signals a decrease in social boundaries between natives and immigrants (Adserà and Ferrer 2015; Rodríguez-García 2015). These boundaries differ in nature. Besides structural marriage market constraints, such as the size and sex ratio of both the immigrant and the native populations (Kalmijn 1998; Chiswick and Houseworth 2011), a range of socioeconomic and cultural factors may discourage the formation of intermarriages. An important role is played by different patterns of labor market inclusion and residential segregation as well as individual preferences and persisting prejudices across groups (Becker 1981; Lam 1988; Kalmijn 1998; Furtado 2012; Potârcă and Mills 2015). In support of the assimilation hypothesis, a large number of studies have documented a positive correlation between immigrant integration and intermarriage (Adserà and Ferrer 2015). The latter is more frequent among highly educated immigrants, who have wider social networks in the host country and share with natives the same criteria of mate selection, such as similarity in education and lifestyle (González-Ferrer 2006; Van Tubergen and Maas 2007; Furtado and Theodoropoulos 2011; Sánchez-Dominguez, de Valk, and Reher 2011).

However, there is an alternative explanation for intermarriage which, contrary to the assimilation hypothesis, is based on the existence of a social distance between natives and immigrants. Building on the status exchange hypothesis (Davis 1941; Merton 1941), we can argue that the larger the socioeconomic differences between natives and immigrants, the greater the immigrants' incentives to marry exogamously. This is because immigrants perceive intermarriage as a means of improving their integration prospects in the host country. An immigrant can expect a number of material returns from marriage to a native, as numerous studies on the intermarriage wage 
premium confirm (Meng and Gregory 2005; Meng and Meurs 2009; Furtado and Trejo 2013). Especially in settings characterized by weak immigrant socioeconomic integration, immigrants may be prone to trade some of their valuable assets (e.g., youth and high levels of education) by marrying less desirable members of the native population (e.g., older and less educated individuals). Empirical support for this comes from recent studies on intermarriage in Australia and the United States (Choi et al. 2012; Balisteri, Joyner, and Kao 2016) as well as in newer countries of choice for immigrants, such as Spain (Cortina Trilla, Esteve, and Domingo 2008) and Italy (Maffioli, Paterno, and Gabrielli 2014; Guetto and Azzolini 2015).

Which of these two hypotheses works better to account for intermarriage formation? Is immigrant integration leading to more or fewer intermarriages? This study focuses on the situation in Italy and provides causal evidence on the nexus between integration and intermarriage by looking at an exogenous change in immigrants' legal status: the acquisition of citizenship. Empirical identification of the causal effect of citizenship acquisition on intermarriage is complicated by problems of endogeneity. Citizenship correlates with a long list of observable and unobservable factors that also affect propensity to intermarry (Zimmermann, Constant, and Gatullina 2009). Compared with noncitizen immigrants, immigrants in possession of host country citizenship are likely to have spent more years in the host country, to have acquired better mastery of the language, and to have developed a wider network of acquaintances. We address the causal identification problem by treating the 2004 and 2007 European Union Eastern enlargements (EUEEs) as quasi-experiments providing exogenous variation in the legal status of immigrants originating from new EU member countries of Eastern Europe, who, upon accession, became EU citizens. To our knowledge, this study is the first to assess the causal effect of citizenship on intermarriage.

We apply a counterfactual technique for aggregate data (i.e., the synthetic control method) to census data from the Italian Register of Marriages. Given that marriages involving Italian women and men originating from Eastern Europe are relatively rare, we consider only marriages between Italian men and foreign women. Our empirical analysis suggests that the two EUEEs had a sizable negative impact on intermarriage involving women from the new EU member countries. The analysis takes into account national group differences in structural marriage market constraints as well as socioeconomic predictors of intermarriage. Therefore, with regard to the two theoretical positions outlined above, the results provide support for the prevalence of the status exchange hypothesis. This can be explained by the particularly low occupational attainment and the precarious legal status of immigrant women in Italy.

The rest of the paper is organized as follows. Section 2 illustrates the links between citizenship acquisition and intermarriage according to both the assimilation 
and the status exchange hypotheses. The research setting of the study is presented in Section 3, which provides detailed descriptions of the institutional discontinuities brought about by the EUEEs as well as the peculiarities of the Italian context. Section 4 describes the empirical strategy as well as the data and the variables employed in the analysis. The results are presented in Section 5. Section 6 concludes, summarizing and discussing the results in the context of the debate on the role of institutions such as marriage and citizenship, and their interplay, in the process of immigrant integration.

\section{Citizenship acquisition and intermarriage}

That citizenship acquisition contributes to reducing the social distance between immigrants and natives is a relatively well-established fact in the literature. From an economic point of view, citizenship not only gives immigrants longer-term and more secure prospects of stability in the host country (Sajons 2016), but also facilitates labor market attainment through higher employment rates (Fougère and Safi 2009; Corluy, Marx, and Verbist 2011), access to more prestigious occupations, and higher wages (Chiswick 1978; Kogan 2003; Gathmann and Keller 2014). From a sociocultural point of view, the possession of citizenship is expected to increase immigrants' likelihood of establishing intimate contacts with natives as a consequence of an enhanced sense of belonging to the host country (Bloemraad, Korteweg, and Yurdakul 2008) and higher civic participation (de Rooij 2012). Moreover, improved legal status can reduce deviant behaviors (Mastrobuoni and Pinotti 2015).

Building on this literature, an exogenous intervention granting access to citizenship to immigrants should foster their socioeconomic integration. However, when considering intermarriage as an outcome, instead of labor market inclusion or political participation, the expected impact of such an exogenous change is not theoretically straightforward. Previous studies have analyzed trends and patterns of intermarriage in the context of the European integration process (Haandrikman 2014; de Valk and Medrano 2014), but without focusing on the causal effect of citizenship acquisition. The few available empirical studies on the topic report either positive (Sánchez-Dominguez, de Valk, and Reher 2011) or nil impact (Engdahl 2014) of citizenship acquisition on immigrants' chances of intermarriage. Other studies assess the causal effect of changes in legal status regulations, finding that stricter regulations increase intermarriage rates (Wang and Wang 2012; Chi 2015), but they do not have a specific focus on citizenship.

Differences in the relationship between citizenship status and intermarriage propensity could stem from the prevalence of the assimilation or the status exchange hypothesis. If, following the former, intermarriage is the result of reduced barriers 
between natives and immigrants, an exogenous positive shift in immigrants' legal status should increase the chances of intermarriage. Immigrants in possession of host country citizenship could have access to better occupational positions and more opportunities to establish contact with potential native partners. At the same time, natives may consider immigrants with host country citizenship to be more desirable partners because of their better socioeconomic conditions and prospects. Therefore, we might expect immigrants' acquisition of citizenship to increase intermarriage. However, the prospect of obtaining citizenship through marriage might work as an incentive for immigrants to enter unions with natives. If a status exchange mechanism prevails, an exogenous positive shift in immigrants' legal status would eliminate part of their rationale for the exchange and thus reduce intermarriage propensity. Therefore, we might expect immigrants' acquisition of citizenship to reduce intermarriage. In broader terms, a negative impact of citizenship acquisition on immigrants' intermarriage propensity would cast doubt on a naive interpretation of intermarriage as an indicator of immigrant integration (Adserà and Ferrer 2015; Alba and Foner 2015; Rodríguez-García 2015).

Before considering these theoretical arguments further, three qualifications are necessary. First, the two scenarios do not imply a strict contradiction at the individual level. The existence of a status exchange mechanism does not preclude integration as a codeterminant of intermarriage. For example, even within a status exchange scenario a minimum level of integration, such as the possession of language and country-specific skills, is expected to favor immigrants' chances of marrying a native. At the same time, even highly assimilated immigrants could find it profitable to marry a native because this would further contribute to their integration through the facilitated access to citizenship and spillovers of country-specific social and human capital (Furtado and Trejo 2013). Therefore, at the individual level an exogenous change in legal status can have simultaneously positive and negative effects on immigrants' intermarriage propensity. Establishing which of the two hypotheses prevails at the aggregate level is at the core of the empirical analysis of this paper.

Second, whether and to what extent negative or positive effects prevail will depend on the specific characteristics of the immigrant group and the host country. Negative effects should be stronger the worse the socioeconomic conditions of immigrants: that is, the more likely it is that intermarriage is based on status exchange. Heterogeneity in the negative effects is possibly related to differences in the mechanisms underlying them. On the one hand, immigrants' exogenous acquisition of citizenship can hinder migrant-native couple formation, thus reducing the number of partnerships. On the other hand, preexisting migrant-native couples may choose to cohabit as a response to an intervention granting host country citizenship. In this case, the observed reduction in intermarriages would leave the actual number of partnerships largely unchanged after the intervention. While the latter mechanism could be in action independently from the 
level of immigrants' socioeconomic integration, intermarriages involving members of the most disadvantaged immigrant groups are more likely to decrease also as a result of a reduced number of partnerships.

Finally, it is possible that negative effects are likely to manifest themselves more rapidly than positive ones. Negative effects arise as a consequence of a sudden and drastic reduction in material gains obtainable via marriage. Instead, the channels through which citizenship exerts positive effects are related to slower changes in immigrants' integration and sense of belonging in the host country. Moreover, citizenship may increase immigrants' reservation value in partner choice and, consequently, spouse search duration. So positive effects are likely to be more delayed. This implies that our estimates might be biased toward negative effects, which are more easily detectable than positive ones.

\section{The European Union Eastern enlargements and intermarriage in Italy}

\subsection{The discontinuity in immigrants' legal status brought about by the European Union Eastern enlargements}

To assess the causal effect of citizenship status on intermarriage, we consider the institutional discontinuities produced by the two EUEEs that took place in 2004 and 2007. The same institutional discontinuity has been used in earlier studies to assess the impact of legal status on immigrant crime (Mastrobuoni and Pinotti 2015). These two enlargements involved ten Eastern European countries. ${ }^{3}$ Eight countries joined the EU in 2004: the Czech Republic, Estonia, Hungary, Latvia, Lithuania, Poland, Slovakia, and Slovenia. Two more countries, Romania and Bulgaria, joined the EU in 2007. Immigrant women originating from these ten Eastern European countries represent the focus of our research (treated units) because upon EU accession they became EU citizens and thus experienced a sudden and positive change in their legal status in Italy. However, before proceeding with the identification strategy employed (described in Section 4), we need to look more closely at this specific policy change. Some have argued that EU citizenship is not a perfect substitute for national citizenship of the host country. For example, the former may not allow immigrants to vote in national elections, so the positive impact on a sense of belonging to the host country may be smaller. Nonetheless, it should be emphasized that EU citizenship ensures fundamental advantages relative to non-EU citizenship. Most significantly for our purposes, citizens

\footnotetext{
${ }^{3}$ We do not consider the two other countries that joined the EU in 2004, Cyprus and Malta.
} 
of new member countries are able to settle and look for a job in any other country within the EU without being subject to legal limitations. So, all other things being equal, immigrants residing in Italy who possess EU citizenship enjoy more secure legal status and have better integration prospects than immigrants with non-EU citizenship.

Several EU countries imposed temporary restrictions on the free movement of immigrant workers from new member countries. For instance, Italy imposed restrictions on citizens from the 2004 EUEE countries until the first half of 2006 and only fully eliminated restrictions on citizens from the 2007 EUEE countries at the beginning of 2012. These restrictions may have diluted the effects of the EUEEs and led to lower estimates of their real impact on intermarriage. However, in spite of these restrictions, Italy did record a marked increase in the size of the immigrant population from the new EU member countries, as also happened in other European countries (Kahanec and Zimmermann 2010). The presence of greater numbers of potential foreign partners following the EUEEs could mechanically translate into a greater number of intermarriages and thus confound the estimate of the EUEEs' net effects on intermarriage (see Figure 2). To handle this issue, in the empirical analyses we weight the number of intermarriages for the size and the female ratio of each immigrant group (see Subsection 4.2).

Table 1: Timeline of the decisions and actual enforcement of the 2004 and 2007 EUEEs

\begin{tabular}{|c|c|c|c|c|c|c|c|}
\hline 2000 & 2001 & 2002 & 2003 & 2004 & 2005 & 2006 & 2007 \\
\hline \multicolumn{8}{|c|}{2004 EUEE } \\
\hline & & $\begin{array}{l}\text { EU Council } \\
\text { decision }\end{array}$ & $\begin{array}{c}\text { Treaty } \\
\text { signature }\end{array}$ & Accession & & & \\
\hline & & Dec 13 & Apr 16 & May 1 & & & \\
\hline & & & & \multicolumn{4}{|c|}{2007 EUEE } \\
\hline & & & & $\begin{array}{c}\text { EU Council } \\
\text { decision }\end{array}$ & $\begin{array}{c}\text { Treaty } \\
\text { signature }\end{array}$ & & Accession \\
\hline & & & & Dec 17 & Apr 25 & & Jan 1 \\
\hline
\end{tabular}

Finally, as shown in Table 1, the enlargements did not occur without prior announcement. The timing of the decision process opened up the possibility of anticipation effects. For instance, if the status exchange hypothesis is true, Romanian and Bulgarian immigrants could already opt not to marry a native in 2006, being aware that, starting from 2007, they would be granted EU citizenship anyway. To take such possible anticipation effects into account, in the empirical analyses the dates of both EUEEs are set in the second to last year before the actual date of admission. 


\subsection{Intermarriage in the Italian setting}

Certain peculiarities in the immigration and intermarriage patterns make Italy an interesting case study and allow the formulation of more precise research hypotheses in accordance with the theoretical and empirical expectations discussed above. To begin with, Italy is a new destination for international migration and has received significant and highly feminized migration inflows, especially from Eastern European countries, since the early 2000s. Marriages involving at least one foreigner have increased dramatically, rising from fewer than 5\% of total solemnized marriages in 1996 to $14.8 \%$ in 2012. ${ }^{4}$ As Figure 1 shows, most intermarriages occur between native men and foreign women (about 8 in 10 in 2012). Mirroring the great migration inflows from Central and Eastern Europe, more than half of the immigrant wives are of Eastern European ancestry (ISTAT 2013). Marriages between Italian women and foreign men are quantitatively much less significant and also differ strikingly with respect to the national composition of the foreign partners, since only about $15 \%$ involve Eastern European men (ISTAT 2013). This impedes implementation of the same analyses on marriages involving Italian women and foreign men.

Migrant-native couples in Italy are also characterized by striking deviations from the standard patterns of assortative mating based on age and education that are observed among couples consisting of two native or two migrant individuals. Mixed couples are significantly more likely to comprise poorly educated, older Italian men and younger, better-educated immigrant women (Maffioli, Paterno, and Gabrielli 2014; Guetto and Azzolini 2015). These patterns may be accounted for, on the one hand, by the increasing difficulties faced by poorly educated Italian men in finding a (bettereducated) native partner and, on the other hand, by immigrant women's acceptance of marrying down as a potential means to achieve upward social mobility and increased stability in the host country (Maffioli, Paterno, and Gabrielli 2014; Guetto and Azzolini 2015).

\footnotetext{
${ }^{4}$ Here, as in the rest of the empirical analyses, immigrant or foreign status is defined by considering individuals' citizenship and not country of birth.
} 
Figure 1: Proportion of intermarriages and foreign marriages out of total marriages (Italy, 1995-2012)

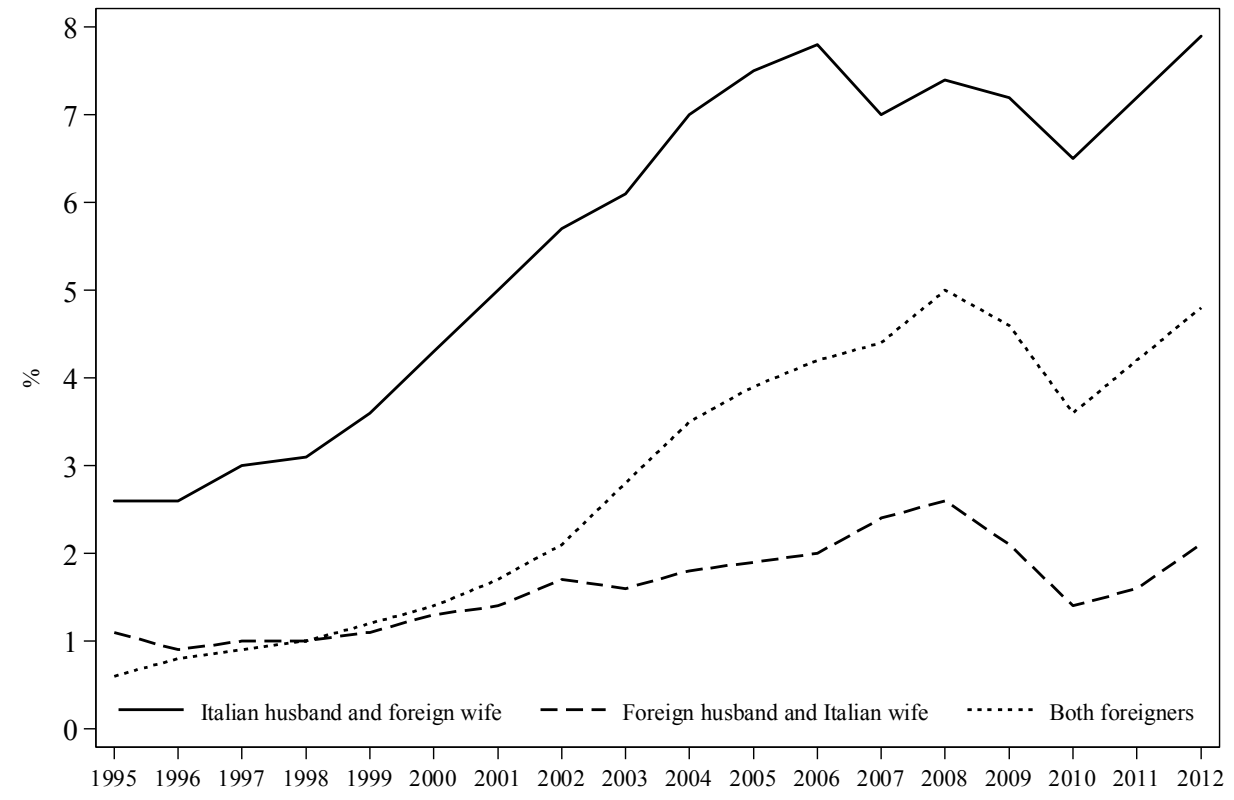

Source: Own elaboration based on data from the Italian Office of Statistics (ISTAT, www.demo.istat.it)

The incentive for immigrant women to marry native Italian men stems from their distinctive patterns of labor market inclusion. Many migrant women are employed in the household and personal services sector and often have doubtful legal status, which increases their risk of working in the lowest-paid occupations and/or in the underground economy (Sciortino 2004; Reyneri 1998, 2008; Fullin and Reyneri 2011). Immigrant women experience a huge occupational downgrade between the last job held in the country of origin and the first job found after migrating, and Eastern European women are more educated and more likely to have already worked in their country of origin, compared to women originating from other areas (Fellini and Guetto 2016). Eastern European women are thus particularly likely to benefit from spillover effects of human capital within intermarriage, which may allow them to partially recover their previous occupational status.

The socioeconomic integration of immigrants in Italy is also hampered by the strict eligibility rules and the long bureaucratic procedures for naturalization, which require ten years of uninterrupted residence for non-EU migrants (Huddleston et al. 2015). The 
possibility of obtaining Italian/EU citizenship through marriage is particularly important for immigrants, and in fact a large proportion of women's naturalizations occur via marriage with an Italian citizen. ${ }^{5}$ Given that immigrants' poor socioeconomic integration may make status exchange an important mechanism underlying the growth of intermarriage in Italy, our first hypothesis can be summarized as follows:

\section{H1: The EUEEs have a negative impact on marriages between Italian men and immigrant women originating from Eastern European countries.}

Furthermore, it can be argued that the EUEEs have heterogeneous effects depending on the level of socioeconomic integration of the specific immigrant groups considered. More precisely, the higher the potential material returns from intermarriage for immigrant women, the stronger the negative effect of the EUEEs. Women originating from poorer countries and experiencing lower levels of socioeconomic integration should be more responsive to a change in the expected material gains from intermarriage. Therefore, our second hypothesis can be summarized as follows:

$\mathrm{H} 2$ : The negative impact of EUEEs on marriages between Italian men and Eastern European immigrant women is stronger the lower the level of socioeconomic integration of the immigrant group.

Unfortunately, detailed data on the economic, cultural, and labor market conditions of each national group considered is not available in Italy, especially for the years before the EUEEs. However, several arguments based on the existing literature and the socioeconomic development of the origin countries lead us to hypothesize that the negative impact of the enlargements should be stronger for the 2007 EUEE countries, Romania and Bulgaria, than for the 2004 EUEE ones. In the preenlargement period Romania had one of the lowest GDPs per capita among Eastern European countries. In the last 15 years Romanians have constantly been among the most represented foreign nationalities in Italy. In 2012 20\% of legally resident foreigners were Romanian and about $17 \%$ of all foreign women married to an Italian man were Romanian. These figures suggest that Romanian women could have the highest potential returns from marrying Italian men. This idea is reinforced by the consideration that Romanian women were overrepresented among those employed, often irregularly, in the

\footnotetext{
${ }^{5}$ Entitlement to Italian citizenship via marriage with an Italian citizen is acquired after a shorter period of residence compared to the standard procedure. Before 2006 this period was six months after marriage solemnization, while since 2006 it has been extended to two years. Official statistics on immigrants' citizenship acquisition via marriage, broken down by gender and country of origin, can be retrieved from the Italian Ministry of the Interior website (http://www.libertaciviliimmigrazione.dlci.interno.gov.it/it/ documentazione/statistica/cittadinanza).
} 
household and personal services sector, compared to women originating from the 2004 EUEE countries (Barbagli 2007). The arguments outlined for Romanian women should extend to Bulgarian women as well: Bulgaria's GDP per capita did not differ much from that of Romania, while Bulgarian women's model of labor market inclusion should be similar to that of Romanian women (Fullin and Reyneri 2011).

Among the 2004 EUEE countries, the Czech Republic and Slovenia had a much higher GDP per capita in the preenlargement period than all other Eastern European countries. Therefore, they should experience a much smaller negative impact, while the remaining 2004 EUEE countries, including Poland, the biggest country in this group, should occupy an intermediate position between the 2007 EUEE countries and the Czech Republic and Slovenia. When comparing Polish and Romanian women, it is possible to argue that Italian men perceive a larger cultural distance from the latter. ${ }^{6}$ First, Italy and Poland share a common Catholic, 'familistic' tradition (Guetto, Luijkx, and Scherer 2015; Matysiak and Vignoli 2013); second, the media often portray Romanians as belonging to the same ethnic group as Romanian Roma (Măndroane 2012), who are depicted as the most crime-prone minority in Italy (Popescu 2008).

\section{Empirical strategy}

\subsection{The synthetic control method}

Obtaining sound causal estimates of the impact of the EUEEs on intermarriage requires a comparison of the trend of intermarriage involving women from a new member country with a counterfactual trend: that is, the trend we would have observed if the country had not joined the EU. Therefore, the key point for retrieving causal estimates of the impact of EU accession on intermarriage is the construction of a credible control group for the new member country. To achieve this we apply the synthetic control method (SCM), developed by Abadie and Gardeazabal (2003), as a data-driven approach for assessing the impact of public policies that take place at an aggregate level and affect aggregate entities. As a novel aspect with respect to previous SCM applications (e.g., Abadie and Gardeazabal 2003; Abadie, Diamond, and Hainmueller 2010, 2015; Billmeier and Nannicini 2013), in this paper SCM is applied not to administrative or political entities but to immigrant groups.

\footnotetext{
${ }^{6}$ The same applies with regard to Romania and Bulgaria and other 2004 EUEE countries. Opinion polls conducted between 2002 and 2007 on representative samples of the Italian population aged over 15 show systematically lower levels of trust in immigrants from the Balkans (ex-Yugoslavia, Albania, Romania, and Bulgaria) compared to immigrants from other Eastern European countries (Demos and Pi 2007).
} 
SCM makes it possible to reproduce the outcome trajectory that the 'treated unit' would have experienced in the absence of the intervention or event of interest (Abadie, Diamond, and Hainmueller 2010). This counterfactual trend is reproduced by a 'synthetic unit' which is built as a weighted combination of control units included in the 'donor pool.' To construct a synthetic unit that reproduces as closely as possible the level and trend of the outcome as well as relevant characteristics of the treated unit $(t)$ in the pretreatment period, SCM assigns weights $(w)$ to the control units included in the donor pool $(c)$. These weights are forced to be positive and sum to 1 (for technical details, see Abadie and Gardeazabal 2003; Abadie, Diamond, and Hainmueller 2010). More precisely, $w$ is chosen to minimize the following quantity:

$$
\left|\sum_{\mathrm{c}=1}^{\mathrm{c}} W_{\mathrm{c}} \mathrm{X}_{\mathrm{c}}-\mathrm{X}_{\mathrm{t}}\right| \text {, }
$$

where $X_{t}$ is defined as a vector of variables measured in the pretreatment period for the treated units, and $X_{c}$ is defined as the corresponding vector of these variables for the control units. If the SCM procedure is successful in building a synthetic unit that approximates the treated unit up to the treatment, it follows that the former is equivalent to the latter in both the observed and the unobserved factors that determine the level and trend in the outcome. The outcome trajectory of the synthetic unit in the posttreatment period represents what we would have observed for the treated unit if it had not received the treatment (i.e., the counterfactual).

It is worth stressing that the identification of an optimal synthetic unit requires that an adequate pool of control units is available, the pretreatment observation window should be sufficiently long, and the relevant predictors included in X must be available for all units. These conditions make SCM a demanding but at the same time more rigorous method compared to more traditional approaches for the causal analysis of aggregate effects like panel regressions and Difference-in-Differences (DiD). SCM can be considered an extension of this class of methods. The key improvement is that, instead of requiring a 'parallel trend' condition as DiD, SCM allows for unit-specific trends and recovers the parallel trend condition by exactly reproducing the counterfactual unit's level and trend, exploiting all available information in the pretreatment period.

Also, the SCM performs better than $\mathrm{DiD}$ when the treated units are few or even only one. This is true especially when considering that the estimated standard errors obtained from DiD regressions with very few treated units are not correct because they rely on asymptotic assumptions which do not hold with a small number of units (Conley and Taber 2001). The approach used by SCM to perform inferential analysis of the results is based on placebo tests (Abadie, Diamond, and Hainmueller 2010). These tests consist of replicating the SCM analysis with every potential control unit in the donor pool as if each of them was affected by the intervention. This makes it possible to 
assess whether the size of the effect estimated for the treated unit is large relative to the distribution of the effects estimated for the units not exposed to the intervention.

\subsection{Data and variables}

We use data from the Italian Register of Marriages (IRM). This data contains information on all the marriages solemnized each year in Italy. ${ }^{7}$ Table 2 lists the 48 national groups used in the analysis. To assess the heterogeneity in the impact of the EUEEs, we produce separate estimates for all national groups affected by the EUEEs. As regards the 2004 EUEE, we pool some national groups together due to small numbers of intermarriages and distinguish between three country groups: (i) Poland, (ii) the Czech Republic and Slovenia (CZ/SL), and (iii) Others (Estonia, Hungary, Latvia, Lithuania, and Slovakia). As regards the 2007 EUEE, we analyze Bulgaria and Romania separately. Besides the treated units, we use as controls nine immigrant groups from Eastern European countries that were not members of the EU during the relevant period and 29 other national groups from non-European countries. Immigrant groups with fewer than ten intermarriages per year are excluded from the analyses because their results would be too volatile. Immigrants from European countries which were already members of the EU before 2004 are also not included in the analysis.

Figure 2 shows the trends in the absolute number of intermarriages for four groups of nationalities identified according to their 'treatment' status and geographical location. The broken vertical line identifies the 2004 EUEE, while the solid vertical line represents the 2007 EUEE. In both cases we allow for anticipation effects, that is, we set the 2004 EUEE at December 31, 2002, instead of May 1, 2004, and the 2007 EUEE at December 31, 2005, instead of January 1, 2007, to take account of the decisionmaking process that preceded the two enlargements and may have influenced individuals' behaviors even before their actual enforcement. Figure 2 shows mere aggregated trends of intermarriages, although some patterns suggesting the existence of EUEE effects should be underlined. Admittedly with different intensities, all groups show a growth in intermarriages in the period 1995-2002. Between 2002 and 2005, marriages between Italian men and women from 2004 EUEE countries (the treated countries, in this period) decrease. Marriages with women from non-European countries (bottom-right panel) also decrease after 2002 but then eventually start to increase again. Intermarriages with women from 2007 EUEE countries, however, increase sharply in

\footnotetext{
${ }^{7}$ These data do not include intermarriages solemnized in a foreign country. However, the existence of such intermarriages would bias our results only to the extent that their incidence differed across countries and over time.
} 
the 2002-2005 period and then suddenly and dramatically decrease after the 2007 EUEE. ${ }^{8}$

\section{Table 2: $\quad$ Treated and control countries}

\begin{tabular}{|c|c|c|c|}
\hline Treated countries (10) & \multicolumn{3}{|l|}{ Control countries (38) } \\
\hline 2004 EUEE countries & \multicolumn{3}{|c|}{ Other Eastern European countries } \\
\hline \multirow[t]{2}{*}{ Poland } & Albania & Croatia** & Russia \\
\hline & Belarus & Macedonia & Serbia-Kosovo-Montenegro \\
\hline Slovenia & Bosnia-Herzegovina & Moldova & Ukraine \\
\hline \multirow[t]{2}{*}{ Czech Republic } & \multicolumn{3}{|c|}{ Other non-EU countries } \\
\hline & Algeria & Dominica & Nigeria \\
\hline Others & Argentina & Dom. Rep. & Peru \\
\hline Estonia & Australia & Ecuador & Philippines \\
\hline Hungary & Brazil & El Salvador & Switzerland \\
\hline Latvia & Canada & Ethiopia & Thailand \\
\hline Lithuania & Cape Verde & Iran & Tunisia \\
\hline \multirow[t]{2}{*}{ Slovakia } & Chile & Japan & Turkey \\
\hline & China & Mauritius & USA \\
\hline 2007 EUEE countries & Colombia & Mexico & Venezuela \\
\hline Bulgaria* & Cuba & Morocco & \\
\hline Romania* & & & \\
\hline
\end{tabular}

Note: Countries in italics are not included in the main analyses but appear in additional analyses that will be made available upon request, as explained in Section 5. Serbia, Kosovo, and Montenegro are considered jointly as they formed one country until 2006.

* Bulgaria and Romania are included in the donor pool for 2004 EUEE treated national groups.

${ }^{* *}$ Croatia entered the EU in 2013 , so it counts as an untreated unit in our analysis.

\footnotetext{
${ }^{8}$ The sudden reduction in intermarriages (see Figure 1) between 2008 and 2010 can be traced back to the introduction of Article 1, Paragraph 15 of Law No. 94/2009, which required foreigners wanting to marry in Italy to have a regular permit to stay in addition to the traditional nulla osta (certificate of legal capacity to marry).
} 
Figure 2: Number of intermarriages by national origin of the wife

2004 EUEE countries

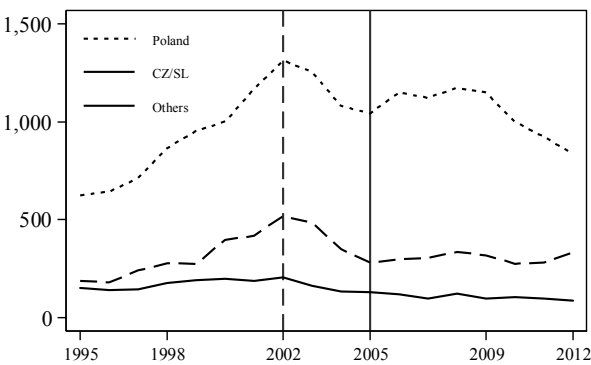

Non-EU Eastern European countries

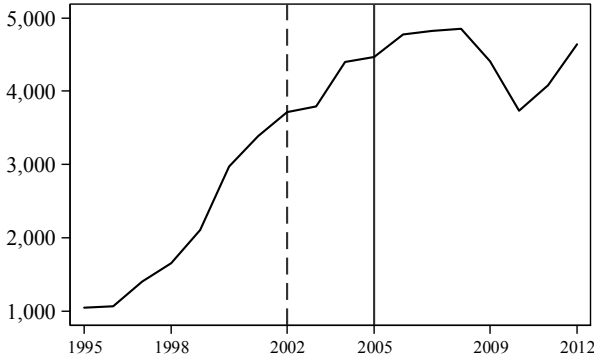

2007 EUEE countries

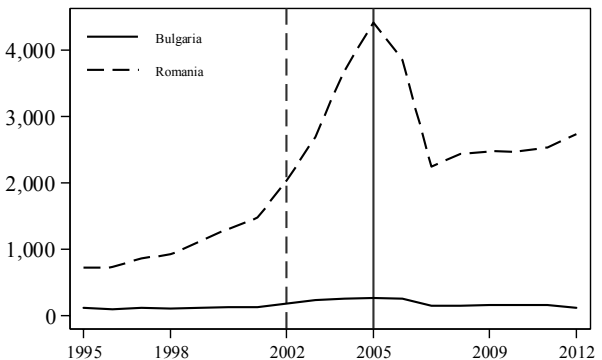

Other non-EU countries

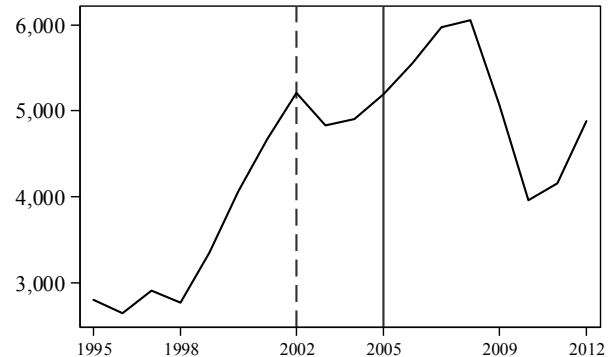

Note: Own elaboration based on IRM data. The broken vertical line identifies the 2004 EUEE, while the solid line represents the 2007 EUEE. EUEEs are anticipated relative to the actual access of the new member states to take account of the decision-making process (see Table 1).

Although Figure 2 provides some indications of the existence of a negative impact of EUEEs on intermarriage, it must be acknowledged that these trends may reflect changes in the size of the immigrant population, which are a probable consequence of the EUEEs and somehow mechanically linked with intermarriage. For example, the growth in intermarriage detected for all groups before 2005 is clearly related to the large immigrant inflows from Eastern Europe that occurred in those years. To account for variation in the structural constraints to intermarriage posed by marriage markets (Kalmijn 1998; Chiswick and Houseworth 2011), instead of using the absolute number of marriages we construct a weighted index that proxies the intermarriage 'propensity' $\left(I_{i n}\right)$ of each national group $(n)$ in a given year $(i)$. Our outcome variable can be represented as follows:

$$
I_{\text {in }}=\frac{\mathrm{M}_{\text {in }}}{\left(\mathrm{S}_{\text {in }} \times \mathrm{F}_{\text {in }}\right)} \times 1,000
$$


where $\mathrm{M}_{\mathrm{in}}$ is the annual number of marriages solemnized between women belonging to the selected nationalities and Italian men, while $S_{i n}$ and $F_{i n}$ are the size and the female ratio of each specific national group respectively. ${ }^{9}$ Besides incorporating the main marriage market constraints identified in the theory, the index $I_{i n}$ makes it possible to control for the positive impact of EUEEs on the immigrant inflows and, subsequently, the size of the immigrant groups in Italy.

To reproduce a synthetic unit for each treated unit, a set of time invariant and timevarying predictors should be selected among those that are theoretically linked to our weighted index of intermarriages and its temporal variations. Yet, country-specific intermarriage propensity levels and trends are difficult to predict from observable factors alone. In our setting, the structural determinants of intermarriage are already included in the outcome variable and, as mentioned above, detailed indicators on immigrants residing in Italy in the pretreatment period are not available. Therefore, our preferred SMC specification includes all pretreatment measures of $I_{i n}$, which capture both the observable and the unobservable components that lie behind union formation (Abadie et al. 2010). To assess the substantial equivalence between the treated and the synthetic units, we include in the analysis a set of socioeconomic characteristics of the origin countries, even if they do not directly contribute to the construction of the synthetic groups (Kaul et al 2016). ${ }^{10}$ We considered three socioeconomic variables measured as country-specific averages in the pretreatment period. First, we include a measure for couples' educational match-up (i.e., the percentage of couples in which the immigrant wife is more educated than the Italian husband) obtained from the IRM data, because couple educational imbalance has been interpreted as an indicator of status exchange (Guetto and Azzolini 2015). Then we use United Nations data on the Human Development Index (HDI, a composite indicator of life expectancy, years of schooling, and per capita GDP) and the net migration rate of the country of origin (given by the difference between immigrants and emigrants per 1,000 inhabitants in a given country, measured over a five-years period). If the status exchange theory holds, immigrant groups from countries scoring low on the HDI and characterized by high emigration rates should exhibit higher values in our intermarriage index.

\footnotetext{
${ }^{9}$ See Appendix I for a more detailed description of the data sources used to quantify the number of immigrants and the female ratio within each national group.

${ }^{10}$ Although alternative specifications employing fewer values and/or the average of the pretreatment outcome lead to substantially identical results, the chosen strategy makes it possible to implement an identical SCM specification across the different groups involved in the analysis.
} 


\section{Empirical results}

\subsection{SCM estimates}

Figure 3 displays the trends of the index of intermarriages $\left(I_{i n}\right)$ observed for the 'real' treated units and the trends estimated through SCM for their respective 'synthetic' ones. SCM performed well because the real pretreatment trends of all the considered groups are precisely approximated by the synthetic unit ones. It should be noted that $I_{i n}$ is fairly similar and stable across immigrant groups in the pretreatment period. This indicates that the growth in the absolute number of intermarriages observed until 2005 (Figure 1) was mostly due to changes in the marriage market structure, rather than declining social boundaries between immigrants and natives.

Figure 3 shows that EU access led to a marked drop in marriages between Italian men and women from both 2004 and 2007 EUEE countries. The decision to allow for anticipation effects is empirically justified, since the index $I_{i n}$ started to decline before the year of the actual EUEEs. To quantify the size of the effect for the 2007 EUEE national groups, we can compare the evolution of the index $I_{i n}$ between 2005 and 2007 for both the treated and the synthetic units. As far as Romania is concerned, the index $I_{\text {in }}$ dropped by $74 \%$, while in the same period its synthetic counterpart increased by $5 \%$. Thus, the causal effect of EU access can be estimated as a $79 \%$ reduction in $I_{i n}$, a result which is almost identical to that of Bulgaria. Compared to the 2007 EUEE, the impact of the 2004 EUEE is markedly less pronounced. In 2004 the magnitude of the negative effect is only slightly larger for immigrant groups from Poland and Others (with an estimated impact of about $40 \%$ and $50 \%$ respectively), compared to those from the Czech Republic and Slovenia, for which the estimated negative impact is about $30 \%$. Therefore, EUEEs had a greater negative impact for women belonging to less affluent and integrated immigrant groups, providing support for the hypothesis that a sudden positive change in legal status reduces intermarriage to a greater extent the larger the socioeconomic disadvantage of the national group concerned and so the more likely status exchange is to play a role in the union. 
Figure 3: Trends in the index of intermarriages: real vs. synthetic groups
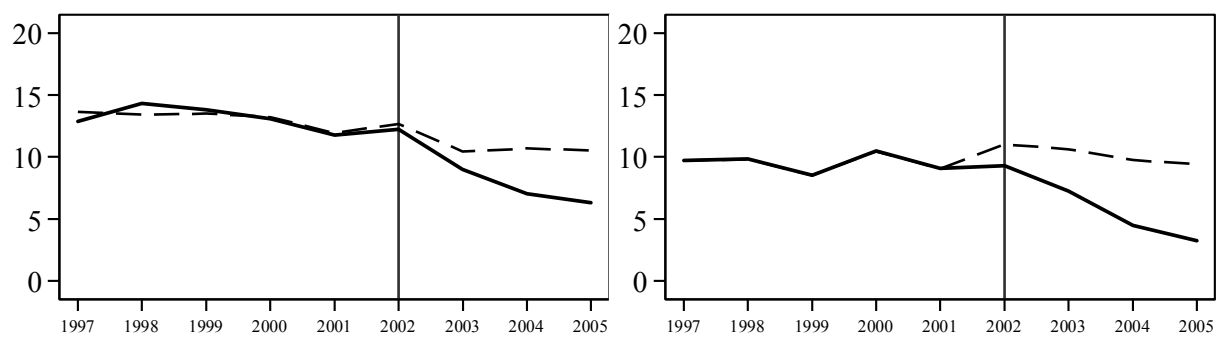

$-\mathrm{CZ} / \mathrm{SL} \quad-\quad$ Synthetic CZ/SL

Others - - Synthetic Others

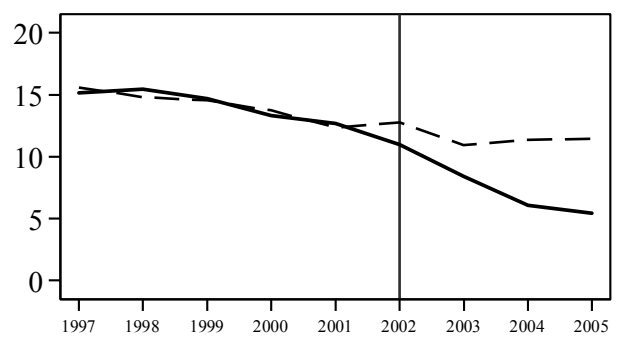

— Poland - Synthetic Poland
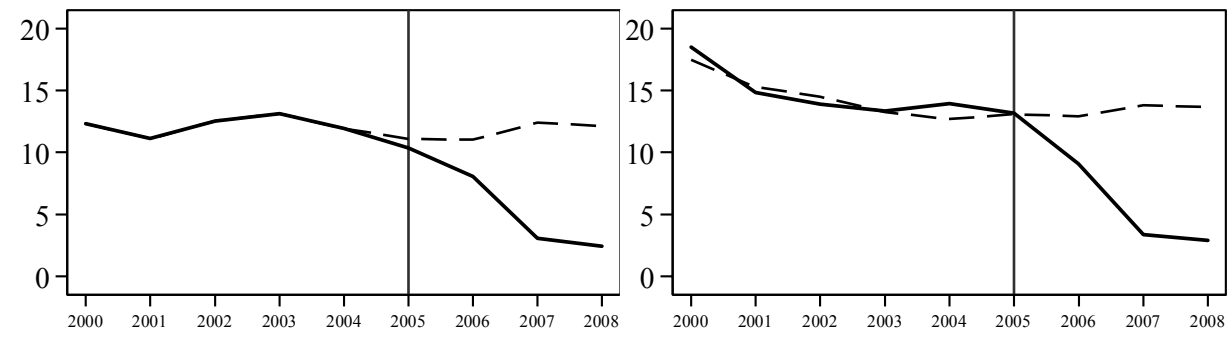

Bulgaria - - Synthetic Bulgaria

— Romania - - Synthetic Romania

Note: Own elaboration on IRM data. The y axis displays the values of the intermarriage index $\left(l_{\text {in }}\right)$.

The weights distribution of the national groups included in the donor pool are shown in Table 3. SCM assigns weights mostly to immigrant groups from low-income countries (the only exception is Japan, used to reproduce Bulgaria's synthetic trend), suggesting the existence of common intermarriage patterns for those national groups. Due to the unavailability of data on couples' educational match-up for small groups in the first years of the series, some of the national groups originally included in the donor pool were dropped (see Table 2). This does not noticeably harm our analysis, as we 
dropped nationalities whose trends in marriages are highly volatile. However, additional analyses employing all 38 national groups of the original donor pool yield results that are qualitatively the same.

Table 3: Country weights in the synthetic units for the 2004 and 2007 EUEEs

\begin{tabular}{|c|c|c|c|c|c|}
\hline & & 2004 EU & & 200 & JEE \\
\hline & CZ/SL & Others & Poland & Bulgaria & Romania \\
\hline Albania & & 0.01 & & 0.01 & \\
\hline Bulgaria & & 0.01 & & & \\
\hline Romania & 0.38 & 0.01 & 0.57 & & \\
\hline Switzerland & & 0.02 & & 0.01 & \\
\hline Ukraine & & 0.01 & & 0.01 & \\
\hline Russian Federation & & 0.02 & & 0.06 & 0.17 \\
\hline Croatia & & 0.01 & & 0.01 & \\
\hline Bosnia and Herzegovina & & 0.10 & & 0.01 & \\
\hline Macedonia & & 0.01 & & & \\
\hline Moldova & & & & 0.01 & \\
\hline Belarus & & 0.01 & & 0.02 & \\
\hline Serbia-Kosovo-Montenegro & & 0.01 & & 0.01 & \\
\hline China & & 0.01 & & 0.01 & \\
\hline Philippines & & 0.02 & & & \\
\hline Japan & & 0.01 & & 0.34 & \\
\hline Thailand & & 0.02 & & 0.01 & \\
\hline Morocco & & 0.01 & & 0.01 & \\
\hline Nigeria & & 0.06 & 0.02 & 0.03 & \\
\hline Cuba & & & & 0.01 & \\
\hline Dominican Republic & & 0.01 & & 0.01 & \\
\hline Mexico & 0.08 & 0.42 & & 0.22 & 0.26 \\
\hline United States of America & & 0.01 & & 0.01 & \\
\hline Argentine & 0.48 & 0.02 & 0.40 & 0.01 & \\
\hline Brazil & & 0.01 & & 0.04 & 0.43 \\
\hline Colombia & 0.06 & & 0.01 & 0.01 & 0.15 \\
\hline Ecuador & & 0.02 & & 0.01 & \\
\hline Peru & & 0.01 & & 0.01 & \\
\hline Venezuela & & 0.15 & & 0.17 & \\
\hline
\end{tabular}

Note: The sum of country weights might differ from 1.00 because of rounding.

Table 4 compares the pretreatment outcome and characteristics of the treated units with their respective synthetics and with a simple average of control units weighted by the number of intermarriages in Italy. In both EUEEs and across all groups the synthetic 
units recover almost identical values on the pretreatment values of $I_{i n}$, which are notably different from donor pool weighted averages, especially for 2007 EUEE national groups.

Table 4: $\quad$ Predictors balance

\begin{tabular}{|c|c|c|c|c|c|c|c|}
\hline & \multicolumn{7}{|c|}{2004 EUEE } \\
\hline & CZ/SL & $\begin{array}{c}\text { Synthetic } \\
\text { CZ/SL }\end{array}$ & Others & $\begin{array}{c}\text { Synthetic } \\
\text { Others }\end{array}$ & Poland & $\begin{array}{l}\text { Synthetic } \\
\text { Poland }\end{array}$ & $\begin{array}{c}\text { Donor } \\
\text { pool } \\
\text { (weighted } \\
\text { average) }\end{array}$ \\
\hline $\begin{array}{l}\text { Wife more educated (\%) } \\
\text { (pretreatment average) }\end{array}$ & 21.49 & 30.32 & 27.96 & 31.21 & 28.58 & 30.37 & 27.03 \\
\hline $\begin{array}{l}\text { Net migration rate } \\
1995-2000\end{array}$ & 0.54 & -1.58 & -0.36 & -0.52 & -1.21 & -1.78 & -3.14 \\
\hline HDI 2000 & 0.81 & 0.72 & 0.77 & 0.68 & 0.78 & 0.72 & 0.68 \\
\hline \multicolumn{8}{|l|}{ Intermarriage index $\left(l_{\text {in }}\right)$} \\
\hline 1997 & 12.86 & 13.63 & 9.72 & 9.70 & 15.15 & 15.59 & 12.60 \\
\hline 1998 & 14.31 & 13.42 & 9.83 & 9.82 & 15.44 & 14.82 & 11.50 \\
\hline 1999 & 13.81 & 13.51 & 8.54 & 8.53 & 14.70 & 14.55 & 12.00 \\
\hline 2000 & 13.09 & 13.22 & 10.47 & 10.46 & 13.31 & 13.73 & 13.70 \\
\hline 2001 & 11.79 & 11.93 & 9.08 & 9.07 & 12.67 & 12.37 & 11.98 \\
\hline \multirow[t]{3}{*}{2002} & 12.25 & 12.68 & 9.31 & 11.02 & 10.98 & 12.77 & 10.37 \\
\hline & \multicolumn{7}{|c|}{2007 EUEE } \\
\hline & Bulgaria & $\begin{array}{l}\text { Synthetic } \\
\text { Bulgaria }\end{array}$ & Romania & $\begin{array}{l}\text { Synthetic } \\
\text { Romania }\end{array}$ & $\begin{array}{c}\text { Donor } \\
\text { pool } \\
\text { (weighted } \\
\text { average) }\end{array}$ & & \\
\hline $\begin{array}{l}\text { Wife more educated (\%) } \\
\text { (pretreatment average) }\end{array}$ & 34.50 & 36.79 & 31.31 & 29.29 & 26.04 & & \\
\hline $\begin{array}{l}\text { Net migration rate } \\
2000-2005\end{array}$ & -2.12 & -1.04 & -0.47 & -1.33 & -3.61 & & \\
\hline HDI 2000 & 0.71 & 0.74 & 0.71 & 0.69 & 0.67 & & \\
\hline \multicolumn{8}{|l|}{ Intermarriage index $\left(l_{\text {in }}\right)$} \\
\hline 2000 & 12.33 & 12.33 & 18.52 & 17.48 & 14.19 & & \\
\hline 2001 & 11.11 & 11.11 & 14.84 & 15.29 & 13.27 & & \\
\hline 2002 & 12.55 & 12.55 & 13.89 & 14.50 & 10.39 & & \\
\hline 2003 & 13.12 & 13.12 & 13.33 & 13.26 & 8.11 & & \\
\hline 2004 & 11.93 & 11.93 & 13.96 & 12.69 & 6.97 & & \\
\hline 2005 & 10.34 & 11.09 & 13.19 & 13.09 & 6.90 & & \\
\hline
\end{tabular}


When looking at the pretreatment average of the share of couples where the wife is more educated, for the 2007 EUEE the synthetic units match the treated ones quite well. This is particularly important here because values for Romania and especially Bulgaria are quite distant from the donor pool average. Consistently with status exchange theory, marriages between Italian men and immigrant women from these low-income countries are more likely to involve a wife who is more educated than the husband (Guetto and Azzolini 2015). Among 2004 EUEE immigrant groups the SCM does not add much, since values for Poland and Others were already very similar to the donor pool average. In the case of Slovenia and Czech Republic the share of couples where the wife is more educated is much lower compared to their synthetic counterpart. This may be due to the fact that the latter is mostly based on Romanian and Argentinian immigrants, who show rather different educational levels and assortative mating patterns relative to the treated national groups. However, in the case of pretreatment averages of HDI and net migration rates of the countries of origin, the synthetic values are always closer to the values recovered for the treated ones compared to donor pool averages. Therefore, our counterfactual analysis is based on the comparison of real and synthetic immigrant groups that are rather similar with respect to a number of socioeconomic characteristics that constitute important predictors of intermarriage behaviors.

\subsection{Significance tests}

To assess the statistical significance of the estimated causal effects, we conduct a series of placebo tests. As described in Section 4, these tests are performed by assigning the 'EUEE treatment' to each of the control countries as if they were treated like the 2004 and 2007 EUEE countries. Figure 4 shows the results of these tests. More precisely, the black lines show the evolution of the gap estimated between the real and the synthetic units as derived from Figure 3, while the thinner gray lines show the same gaps estimated for the control units. Figure 4 shows that the 2007 EUEE had a strongly significant impact on intermarriages solemnized between Italian men and Romanian and Bulgarian women. The significance of the impact is visibly high as the placebo gaps (gray lines) almost never overlap with the 2007 EUEE gap lines in the posttreatment period. 
Figure 4: Estimated gaps between real and synthetic groups (bold black lines) and placebo gaps in the control national groups (gray lines)

\section{EUEE}
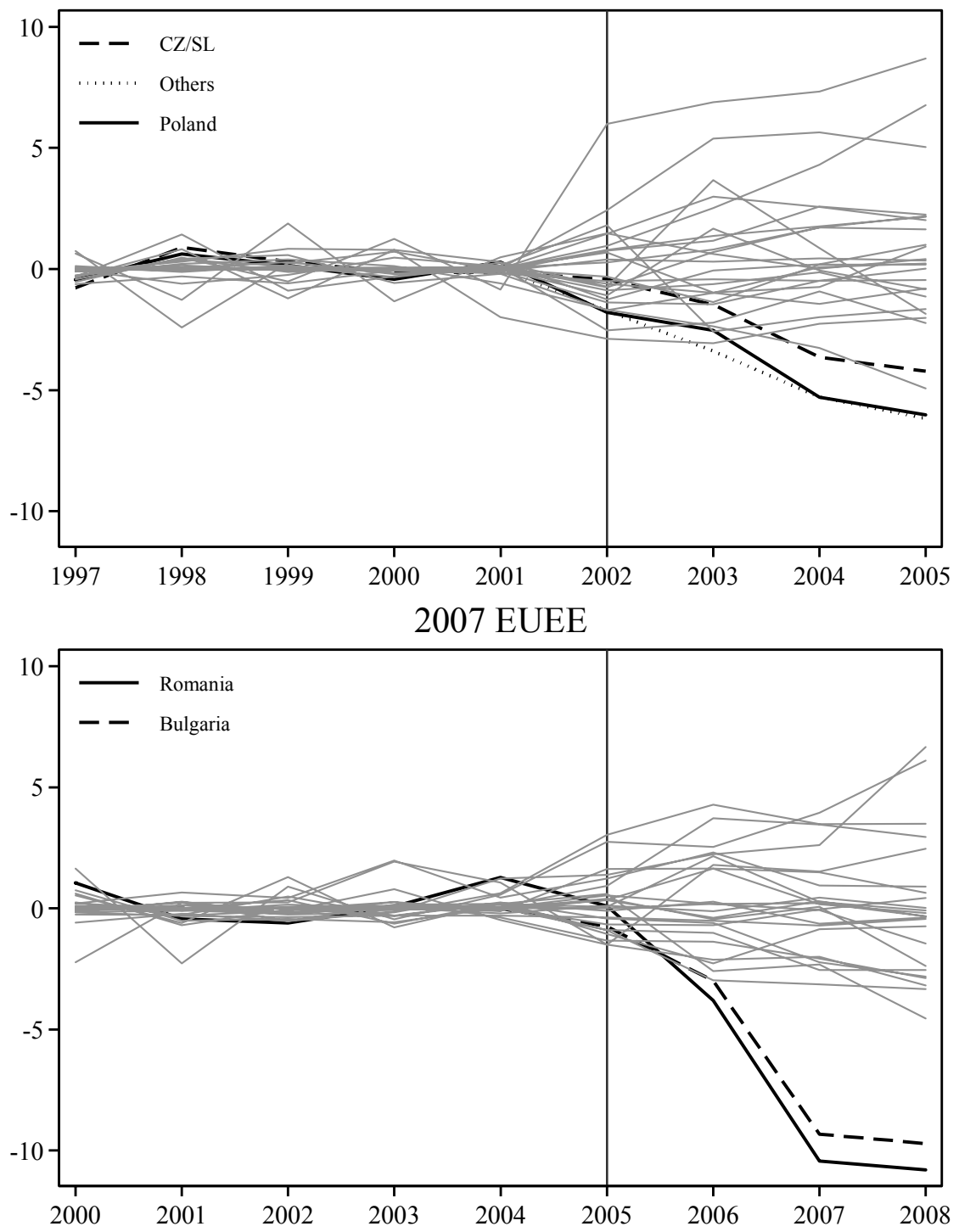

Note: Own elaboration on IRM data. 
With regard to 2004 EUEE nationalities, the evidence of significant effects is slightly weaker. In 2003 the probability of estimating a gap larger than the one estimated for the Czech Republic and Slovenia is .21 (5/24) - that is, a higher level than the one typically adopted in conventional tests of statistical significance (.05) - which would lead us to accept the null hypothesis that the effect is zero. However, in 2004 and 2005 the effect is significant at conventional levels for all treated units. ${ }^{11}$

\subsection{Robustness checks}

The estimated effects could be partly driven by changes in the composition of the immigrant population brought about by the two EUEEs. Our outcome variable takes changes in the size and the female ratio into account, but the immigrant inflows can change also with respect to other relevant predictors of intermarriage, such as age and education. To indirectly test this hypothesis, we examined the evolution of female immigrant inflows from different national origins using Italian Labor Force Survey (ILFS) data. The results of this additional analysis are reported in Appendix II. Women from the two EUEE countries show very similar patterns with respect to both education and age composition, and no noticeable changes around the enlargements are detected (Figures A-1 and A-2). Therefore, this additional check rejects the compositional hypothesis and provides further support for our causal interpretation of the effects of the EUEEs.

Furthermore, as discussed in Section 2, intermarriage can decrease either because preexisting couples have fewer incentives to marry and opt for cohabitation - leaving the actual number of partnerships unchanged - or because fewer migrant-native couples are formed. One might question the substantive relevance of the negative effect of EUEEs if the latter did not influence the actual number of partnerships but only couples' marital status. The counterargument is that marriage implies a longer-term commitment than cohabitation. Entering a marital union with a member of the native population is likely to increase an immigrant's prospects of staying in the host country for several reasons, not least the direct and indirect costs of divorce, which are rather high in Italy (Härkönen and Dronkers 2006). Empirically, we used ILFS data and provided indirect evidence rejecting this 'substitution effect,' thus further fueling our substantial interpretation of the EUEE impact estimates. As shown in Figure A-3 in Appendix II, the incidence of cohabitations with natives did not increase (or decrease)

\footnotetext{
${ }^{11}$ When analyzing the statistical significance of the 2004 EUEE, four placebo units were dropped, as usual in the literature (Abadie, Diamond, and Hainmueller 2010), because of too large root mean squared prediction errors, indicating a poor performance of SCM in reproducing an adequate synthetic trend. For the same reason, two countries were dropped in the 2007 EUEE.
} 
for women originating from countries entering the EU in 2007, remaining at very low levels similar to those of natives and women from the other countries (Guetto et al. 2016). ${ }^{12}$

\section{Conclusions}

The empirical findings show that the 2004 and 2007 EUEEs led to a sharp drop in intermarriage between women originating from the new EU member countries and Italian men. This result points to the importance of status exchange in the formation of intermarriages in a country such as Italy, where immigrants' socioeconomic integration is poor and naturalization is quite difficult to obtain, except by marriage with a native citizen. In the Italian setting, the prospect of obtaining citizenship through marriage works as an important incentive for immigrants to enter unions with natives, which is especially true among immigrants from poorer countries experiencing lower levels of socioeconomic integration. The reduction in intermarriage brought about by the EUEEs amounted to an approximately $80 \%$ decrease in the index of intermarriages for the economically weakest national groups, namely Bulgarians and Romanians. With regard to intermarriages involving women belonging to better-off Eastern European immigrant groups, as in the case of the 2004 EUEE, the impact is still significant, although much weaker. Also, within this latter group, the impact of the EUEE depends on the degree of socioeconomic disadvantage affecting the women of the relevant countries, which ranged from $30 \%$ to $50 \%$.

The evaluation of the impact of citizenship acquisition on intermarriage is proposed as an empirical test of the extent to which an assimilation account can be applied to the observed increase in the number of intermarriages. Taken together, our empirical findings imply that the growth of intermarriage cannot be considered per se as an indicator of higher immigrant integration in the host country (Song 2009; Alba and Foner 2015; Rodríguez-García 2015), especially when marriages involve the most disadvantaged immigrant groups. On the contrary, lack of socioeconomic integration and uncertain prospects of stability in the host country are likely to operate as factors promoting intermarriage. These results call for a rethinking of the role played by institutions such as marriage and citizenship in the process of immigrant integration. Whereas previous research has suggested that marriage and citizenship have independent positive effects on immigrant integration, our study suggests that these two institutions may be alternatives. Changes in naturalization policies or intermarriage

\footnotetext{
${ }^{12}$ A similar exercise could not be replicated for 2004 EUEE countries because immigrant status information in the ILFS data is available only from 2005 onward, making it impossible to have a pretreatment observation for countries entering the EU in 2004.
} 
regulations may have unexpected consequences on immigrants' family behaviors, which in turn may have long-term consequences on their social integration prospects. Intermarriages formed on the basis of status exchange can have short-term positive consequences on immigrant integration through improved legal status, but they may also contribute to an accumulation of socioeconomic disadvantages and family fragilities over the life course. In the Italian case, intermarriages involve the socioeconomically weaker sections of the population (Guetto and Azzolini 2015); they often represent second marriages for individuals who have children from previous unions (Maffioli, Paterno, and Gabrielli 2012); and they are more exposed to the risk of dissolution (González-Ferrer, Hannemann, and Castro-Martin 2016). This fragility can have detrimental effects on the offspring of these households (Amato 2001; McLanahan and Percheski 2008). In turn, less rigid naturalization legislations could exert more profound and longer-term positive consequences on immigrants' integration prospects in the host country - consequences not limited to the 'legal' dimension of integration but extending to the economic and political sphere by granting equal access to the labor market and facilitating immigrants' full participation in civic, cultural, and political life (Bloemraad, Korteweg, and Yurdakul 2008; de Rooij 2012; Gathmann and Keller 2014).

It would be worthwhile to analyze whether the EUEEs have had an impact on the duration and probability of dissolution of intermarriages involving women from the new EU member countries. Unfortunately, the available Italian register data on separations and divorces contains information on the citizenship and country of origin of spouses in only very broad categories (e.g., former Soviet Union, EU Europe, and other European countries), thus impeding the kind of analysis carried out in this paper.

Finally, our results are focused on a specific case study, Italy, which is characterized by pronounced immigrant occupational downgrade after migration, overall weak socioeconomic integration, uncertain prospects of legal stability, and strict conditions for naturalization. Therefore, our results are likely to extend only to countries with a similar context of immigration and integration, such as, for example, those in southern Europe. Further research comparing the impact of EUEEs on intermarriage (as well as the risk of separation/divorce and fertility) in old and new immigration countries would increase our understanding of the effects of the legal status on immigrants' family choices and socioeconomic integration in Europe.

\section{Acknowledgments}

The authors wish to thank Laura Bernardi, Neli Demireva, Lars Niklas Jakobson, Amparo González-Ferrer, Federico Podestà, Enrico Rettore, Emilio Reyneri, Philipp 
Schnell, and Simone Schueller for their useful comments. Raffaele Guetto gratefully acknowledges funding from the European Commission under the H2020-EU.3.6 Programme, project reference 649255 GEMM - Growth, Equal Opportunities, Migration, and Markets. 


\section{References}

Abadie, A. and Gardeazabal, J. (2003). The economic costs of conflict: A case study of the Basque Country. American Economic Review 93(1): 113-132. doi:10.1257/ 000282803321455188 .

Abadie, A., Diamond, A., and Hainmueller, J. (2010). Synthetic control methods for comparative case studies: Estimating the effect of California's tobacco control program. Journal of American Statistical Association 105(490): 493-505. doi:10.1198/jasa.2009.ap08746.

Abadie, A., Diamond, A., and Hainmueller, J. (2015). Comparative politics and the synthetic control method. American Journal of Political Science 59(2): 495-510. doi:10.1111/ajps.12116.

Adserà, A. and Ferrer, A. (2015). Immigrants and demography: Marriage, divorce, and fertility. In: Chiswick, B.R. and Miller, P.W. (eds.). Handbook of the economics of international migration. Amsterdam: Elsevier: 315-374. doi:10.1016/b978-0444-53764-5.00007-4.

Alba, R.D. and Golden, R.M. (1986). Patterns of ethnic marriage in the United States. Social Forces 65(1): 202-223. doi:10.2307/2578943.

Alba, R. and Foner. N. (2015). Mixed unions and immigrant-group integration in North America and Western Europe. Annals of the American Academy of Political and Social Science 662(1): 38-56. doi:10.1177/0002716215594611.

Amato, P.R. (2001). Children of divorce in the 1990s: An update of the Amato and Keith (1991) meta-analysis. Journal of Family Psychology 15(3): 355-370. doi:10.1037/0893-3200.15.3.355.

Balistreri, S.K., Joyner, K., and Kao, G. (2016). Citizenship for youth? The spousal age gap among immigrant marriages. Bowling Green: Bowling Green State University, Center for Family and Demographic Research.

Barbagli, M. (2007). $1^{\circ}$ Rapporto sugli immigrati in Italia. Rome: Ministero dell'Interno.

Becker, G. (1981). A treatise on the family. Harvard: Harvard University Press.

Bloemraad, I., Korteweg, A., and Yurdakul, G. (2008). Citizenship and immigration: Multiculturalism, assimilation, and challenges to the nation-state. Sociology 34(1): 153-179. doi:10.1146/annurev.soc.34.040507.134608. 
Billmeier, A. and Nannicini, T. (2013). Assessing economic liberalization episodes: A synthetic control approach. Review of Economics and Statistics 95(3): 983-1001. doi:10.1162/REST_a_00324.

Chi, M. (2015). Improved legal status as the major source of earnings premiums associated with intermarriage: Evidence from the 1986 IRCA amnesty. Review of Economics of the Household: 1-16. doi:10.1007/s11150-015-9305-x.

Chiswick, B.R. (1978). The effect of Americanization on the earnings of foreign-born men. Journal of Political Economy 86(5): 897-921. doi:10.1086/260717.

Chiswick, B.R. and Houseworth, C. (2011). Ethnic intermarriage among immigrants: Human capital and assortative mating. Review of Economics of the Household 9(2): 149-180. doi:10.1007/s11150-010-9099-9.

Choi, K.H., Tienda, M., Cobb-Clark, D., and Sinning, M. (2012). Immigration and status exchange in Australia and the United States. Research on Social Stratification and Mobility 30(1): 49-62. doi:10.1016/j.rssm.2011.08.002.

Conley, T.G. and Taber, C.R. (2011). Inference with 'difference in differences' with a small number of policy changes. Review of Economics and Statistics 93(1): 113125. doi:10.1162/REST_a_00049.

Corluy, V., Marx, I., and Verbist, G. (2011). Employment chances and changes of immigrants in Belgium: The impact of citizenship. International Journal of Comparative Sociology 52(4): 350-368. doi:10.1177/0020715211412112.

Cortina Trilla, C., Esteve, A., and Domingo, A. (2008). Marriage patterns of the foreign-born population in a new country of immigration: The case of Spain. International Migration Review 42(4): 877-902. doi:10.1111/j.1747-7379. 2008.00151.x.

Davis, K. (1941). Intermarriage in caste societies. American Anthropologist 43(3): 376395. doi:10.1525/aa.1941.43.3.02a00030.

Demos and Pi (2007). Gli Italiani e l'immigrazione. Rapporto Aprile 2007. http://www.demos.it/a00020.php.

de Rooij, E.A. (2012). Patterns of immigrant political participation: Explaining differences in types of political participation between immigrants and the majority population in Western Europe. European Sociological Review 28(4): 455-481. doi:10.1093/esr/jcr010. 
de Valk, H.A.G. and Medrano, J.D. (2014). Guest editorial on meeting and mating across borders: Union formation in the European Union single market. Population, Space and Place 20(2): 103-109. doi:10.1002/psp.1768.

Engdahl, M. (2014). Naturalizations and the economic and social integration of immigrants. Uppsala: Uppsala Center for Labor Studies, Working paper 2014: 6.

Fellini, I. and Guetto, R. (2016). I percorsi lavorativi degli immigrati in Italia: Declassamento occupazionale e intrappolamento [Immigrants' labour market trajectories in Italy: Occupational downgrade and entrapment]. Paper presented at the first SISEC conference (Società Italiana di Sociologia EConomica), Rome, 26-28 January 2017.

Fougère, D. and Safi, M. (2009). Naturalization and employment of immigrants in France (1968-1999). International Journal of Manpower 30(1/2): 83-96. doi:10.1108/01437720910948410.

Fullin, G. and Reyneri, E. (2011). Low unemployment and bad jobs for new immigrants in Italy. International Migration 49(1): 118-147. doi:10.1111/j.1468-2435. 2009.00594.x.

Furtado, D. (2012). Human capital and interethnic marriage decisions. Economic Inquiry 50(1): 82-93. doi:10.1111/j.1465-7295.2010.00345.x.

Furtado, D. and Theodoropoulos, N. (2011). Interethnic marriage: A choice between ethnic and educational similarities. Journal of Population Economics 24(4): 1257-1279. doi:10.1007/s00148-010-0319-7.

Furtado, D. and Trejo, S. (2013). Interethnic marriages and their economic effects. In: Constant, A.F. and Zimmermann, K.F. (eds.). International handbook on the economics of migration. Cheltenham: Edward Elgar: 276-292. doi:10.4337/9781782546078.00024.

Gathmann, C. and Keller, N. (2014). Returns to citizenship? Evidence from Germany's recent immigration reforms. Berlin: DIW, SOEP papers 656-2015.

González-Ferrer, A. (2006). Who do immigrants marry? Partner choice among single immigrants in Germany. European Sociological Review 22(2): 171-185. doi:10.1093/esr/jci050.

González-Ferrer, A., Hannemann, T., and Castro-Martín, T. (2016). Partnership formation and dissolution among immigrants in the Spanish context. Demographic Research 35(1): 1-30. doi:10.4054/DemRes.2016.35.1.

Gordon, M. (1964). Assimilation in American life. New York: Oxford University Press. 
Guetto, R., Mancosu, M., Scherer, S., and Torricelli, G. (2016). The spreading of cohabitation as a diffusion process: Evidence from Italy. European Journal of Population 32(5): 661-686. doi:10.1007/s10680-016-9380-6.

Guetto, R., Luijkx, S., and Scherer, S. (2015). Religiosity, gender attitudes and women's labour market participation and fertility decisions in Europe. Acta Sociologica 58(2): 155-172. doi:10.1177/0001699315573335.

Guetto, R. and Azzolini, D. (2015). An empirical study of status exchange through migrant/native marriages in Italy. Journal of Ethnic and Migration Studies 41(13): 2149-2172. doi:10.1080/1369183X.2015.1037725.

Haandrikman, K. (2014). Binational marriages in Sweden: Is there an EU effect? Population, Space and Place 20(2): 177-199.

Härkönen, J. and Dronkers, J. (2006). Stability and change in the educational gradient of divorce: A comparison of seventeen countries. European Sociological Review 22(5): 501-517.

Huddleston, T., Bilgili, Ö., Joki, A.L., and Vankova, Z. (2015). Migrant Integration Policy Index 2015. Barcelona/Brussels: CIDOB and MPG.

ISTAT (2013). Il matrimonio in Italia, anno 2012 [Marriage in Italy, year 2012]. Rome: Istituto Nazionale di Statistica [National Institute of Statistics].

Kahanec, M. and Zimmermann, K.F. (2010). Migration in an enlarged EU: A challenging solution? In: Keereman, F. and Szekely, I. (eds.). Five years of an enlarged EU. Berlin: Springer: 63-94. doi:10.1007/978-3-642-12516-4_5.

Kalmijn, M. (1998). Intermarriage and homogamy: Causes, patterns, trends. Annuиal Review of Sociology 24: 395-421. doi:10.1146/annurev.soc.24.1.395.

Kaul, A., Klößner, S., Pfeifer, G., and Schieler, M. (2016). Synthetic control methods: Never use all pre-intervention outcomes as economic predictors [unpublished]. http://www.oekonometrie.uni-saarland.de/papers/SCM_Predictors.pdf.

Kogan, I. (2003). Ex-Yugoslavs in the Austrian and Swedish labour markets: The significance of the period of migration and the effect of citizenship acquisition. Journal of Ethnic and Migration Studies 29(4): 595-622. doi:10.1080/ 1369183032000123413.

Lam, D. (1988). Marriage markets and assortative mating with household public goods: Theoretical results and empirical implications. Journal of Human Resources 23(4): 462-487. doi:10.2307/145809. 
Maffioli, D., Paterno, A., and Gabrielli, G. (2012). Transnational couples in Italy: Characteristics of partners and fertility behaviour. In: Kim, D.-S. (ed.). Marriage: Global trends and diversity. Seoul: IUSSP-Statistics Korea, Korea Institute for Health and Social Affairs: 279-319.

Maffioli, D., Paterno, A., and Gabrielli, G. (2014). International married and unmarried unions in Italy: Criteria of mate selection. International Migration 52(3): 160-176. doi:10.1111/imig.12049.

Măndroane, I.D. (2012). Roma, Romanian, European: A media framed battle over identity. Critical Approaches to Discourse Analysis across Disciplines 5(2): 102-119.

Mastrobuoni, G. and Pinotti, P. (2015). Legal status and the criminal activity of immigrants. American Economic Journal: Applied Economics 7(2): 175-206. doi:10.1257/app.20140039.

Matysiak, A. and Vignoli, D. (2013). Diverse effects of women's employment on fertility: Insights from Italy and Poland. European Journal of Population 29(3): 273-302. doi:10.1007/s10680-013-9287-4.

McLanahan, S. and Percheski, C. (2008). Family structure and the reproduction of inequalities. The Annual Review of Sociology 34: 257-276. doi:10.1146/ annurev.soc.34.040507.134549.

Meng, X. and Gregory, R.G. (2005). Intermarriage and the economic assimilation of immigrants. Journal of Labor Economics 23(1): 135-174. doi:10.1086/425436.

Meng, X. and Meurs, D. (2009). Intermarriage, language, and economic assimilation process: A case study of France. International Journal of Manpower 30(1/2): $127-144$.

Merton, R.K. (1941). Intermarriage and the social structure: Fact and theory. Psychiatry 4(3): 361-374. doi:10.1080/00332747.1941.11022354.

Popescu, T. (2008). Immigration discourses: The case of Romanian immigrants in Italy. The Journal of Linguistic and Intercultural Education 1: 31-43.

Potârcă, G. and Mills, M. (2015) Racial preferences in online dating across European countries. European Sociological Review 31(3): 326-341.

Reyneri, E. (1998). The role of the underground economy in irregular migration to Italy: Cause or effect? Journal of Ethnic and Migration Studies 24(2): 313-331. 
Reyneri, E. (2008). Italy. In: Honekopp, E. and Mattila, H. (eds.). Permanent or circular migration? Policy choices to address demographic decline and labour shortages in Europe. Budapest: IOM: 109-148.

Rodríguez-García, D. (2015). Intermarriage and integration revisited: International experiences and cross-disciplinary approaches. Annals of the American Academy of Political and Social Science 662(1): 8-36. doi:10.1177/0002716215601397.

Sajons, C. (2016). Does granting citizenship to immigrant children affect family outmigration? Journal of Population Economics 29(2): 395-420. doi:10.1007/s00148-015-0573-9.

Sánchez-Domínguez, M., de Valk, H.A.G., and Reher, D. (2011). Marriage strategies among immigrants in Spain. Review of International Sociology 69(M1): 139166. doi:10.3989/ris.2011.iM1.389.

Sciortino, G. (2004). Immigration in a Mediterranean welfare state: The Italian experience in comparative perspective. Journal of Comparative Policy Analysis: Research and Practice 6(2): 111-129. doi:10.1080/1387698042000273442.

Song, M. (2009). Is intermarriage a good indicator of integration? Journal of Ethnic and Migration Studies 35(2): 331-348.

Van Tubergen, F. and Maas, I. (2007). Ethnic intermarriage among immigrants in the Netherlands: An analysis of population data. Social Science Research 36(3): 1065-1086. doi:10.1016/j.ssresearch.2006.09.003.

Wang, C. and Wang, L. (2012). The effects of 9/11 on intermarriage between natives and immigrants to the US. Review of Economics of the Household 10(2): 171192. doi:10.1007/s11150-011-9136-3.

Zimmermann, K.F., Constant, A.F., and Gatullina, L. (2009). Naturalization proclivities, ethnicity and integration. International Journal of Manpower 30(1/2): 70-82. doi:10.1108/01437720910948401. 


\section{Appendix I}

\section{Quantifying the presence of immigrants by nationality and gender}

Two official sources can be employed to measure the number of immigrants and the female ratio within each national group: the municipality registers on all regularly resident individuals and the Ministry of Interior records on foreigners holding a regular permit to stay. Both sources have pros and cons, and neither of them is ideally suited to estimate the actual size of the immigrant population per se.

A common, unavoidable shortcoming of the two sources is that neither of them contains information on irregular migrants. This is an issue since, before 2009, irregular migrants could marry an Italian man. Municipality registers on residents have three main additional disadvantages. First, they are not updated often and so, because of geographical mobility, there may be cases of individuals being registered twice. The lists are updated at the same time as the population census, which takes place every ten years. This implies that data is closer to the 'true' number of migrants in the census year and progressively deteriorates. Second, there are cases of immigrants who are in the country legally but who are not listed in the municipality registers, or are listed only after some delay. Finally, before 2001 national data on immigrant residents, disaggregated by citizenship and gender, is available only for the 50 largest groups, this impeding the study of small migrant groups.

Data on permits to stay would overcome many of these issues, as it is complete and does not suffer to the same extent from delayed registrations. Moreover, until 2008 this data did not include accompanied minors (i.e., younger than 14), which slightly improves the municipality data as minors do not constitute a real 'pool' of potential spouses. However, these data have three disadvantages as well. First, although the data includes migrants with permits to stay at least three months, they might overestimate the potential pool of partners as they include individuals who do not register at the municipality because of their short stay in the country. Second, it could happen that immigrants are counted more than once because multiple permits can be issued to the same individual in special or transitional circumstances. Finally, since 2007 citizens of new member countries are no longer included in the data on permits to stay, while they still have to be included in municipality registers, like all other residents.

Since the two series are highly correlated in our pooled sample (about .9), we use both of them. To reduce noise in the data for small countries we smooth the two series. Then, for the analysis of the 2004 EEUE, where we look at marriages solemnized from 1997 on, we focus only on permits to stay data; information on legal residents is not available for all countries of origin before 2001 and, when available, it is likely to be of poor quality since we focus on the second half of the 1990s (thus, close to the 2001 
census). The observational window considered in the analysis of the 2007 EEUE spans from 2000 to 2008, so information on residents tends to be complete and much more reliable, which means it can be considered jointly with information on permits to stay. In this case we take the average of the two series but for the years 2007 and 2008, because starting from 2007 citizens of new UE member countries have been excluded from permits to stay data.

As robustness checks, we replicated the SCM analyses presented in Section 5 using the data on permits to stay and legal residents separately. For the 2004 EUEE we find qualitatively similar results on the impact of EU accession, although some differences are detected in the levels of intermarriage in the first years of the series (but data on legal residents for those years could only be extrapolated). Also, for the 2007 EUEE our estimates do not vary regardless of the data employed. That is, the difference in the impact of EU accession between 2004 and 2007 cannot be ascribed to differences in the operationalization of the weighted number of intermarriages. These additional analyses are available upon request. 


\section{Appendix II}

\section{Robustness checks}

Figure A-1: Proportion of tertiary-educated women out of total number of immigrant women, by national group and year of arrival

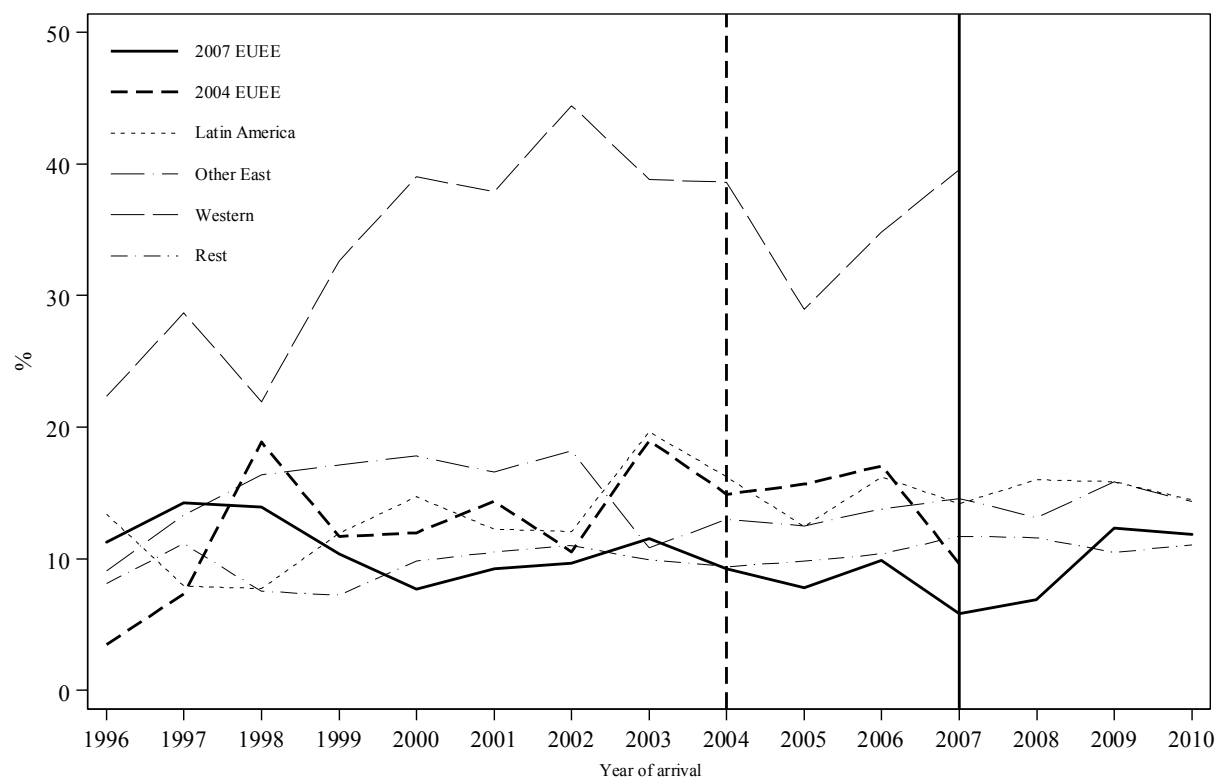

Note: Own elaboration on ILFS data. Weighted estimates. Data for 2004 EUEE and Western countries are not shown after 2007 because of small sample size. The broken vertical line identifies the 2004 EUEE, while the solid line represents the 2007 EUEE. 
Figure A-2: Proportion of women aged under 40 out of total number of immigrant women, by national group and year of arrival

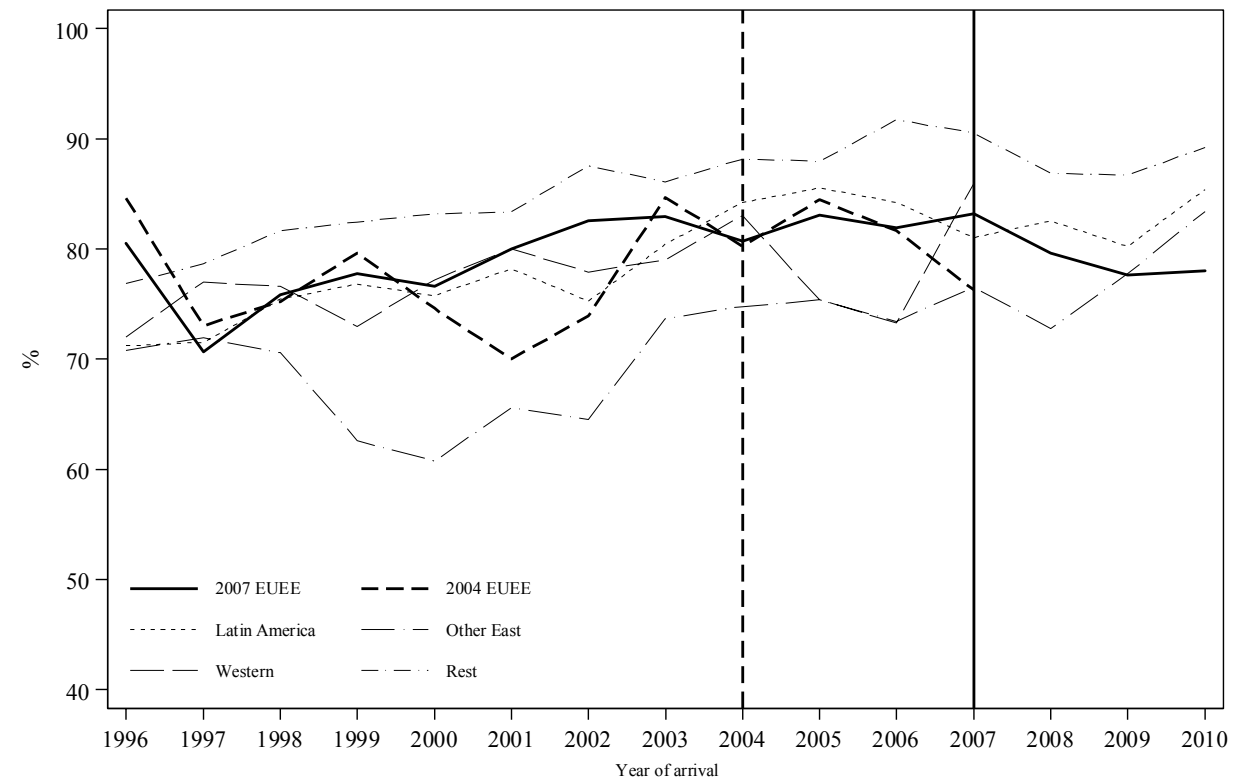

Note: Own elaboration on ILFS data. Weighted estimates. Data for 2004 EUEE and Western countries are not shown after 2007 because of small sample size. The broken vertical line identifies the 2004 EUEE, while the solid line represents the 2007 EUEE. 
Figure A-3: Proportion of women cohabiting with a native man out of total number of immigrant women living in Italy, by national group and year

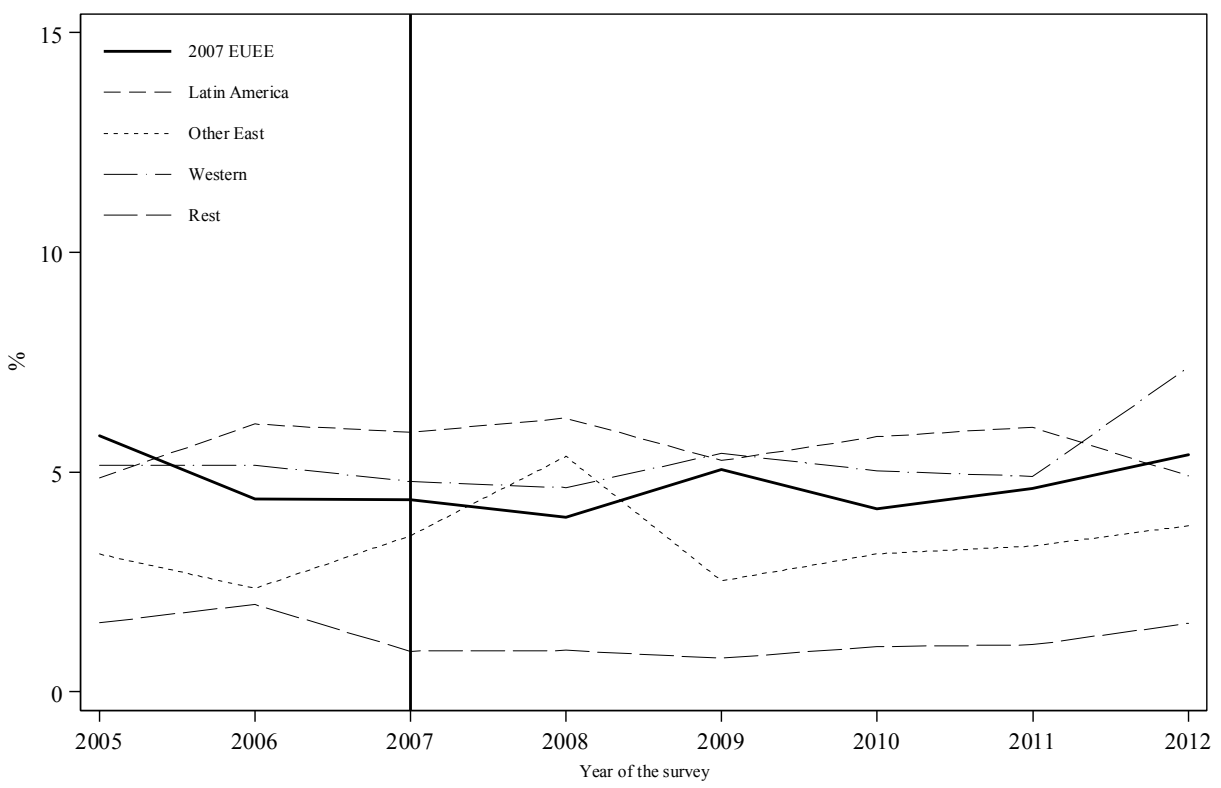

Note: Own elaboration on ILFS data. Weighted estimates. The solid vertical line identifies the 2007 EUEE. 
Azzolini \& Guetto: The impact of citizenship on intermarriage 